\title{
Średniowiecze bez katarów? Najważniejsze nurty w bieżącej dyskusji na temat dysydencji katarskiej
}

Z dwóch, a może nawet $\mathrm{z}$ trzech powodów warto dziś opisać stan badań nad średniowieczną dysydencją religijną nazywaną tradycyjnie kataryzmem. Pierwszy powód jest taki, że zagadnienie to cieszy się od niedawna znacznym zainteresowaniem także w Polsce (wystarczy wskazać książki Joanny Borkowskiej ${ }^{1}$, Mariusza Dobkowskiego ${ }^{2}$ i Piotra Czarneckiego ${ }^{3}$ ). Drugie uzasadnienie to międzynarodowa debata, która toczy się na temat tego zjawiska historyczno-religijnego szczególnie żywo od lat dziewięćdziesiątych ubiegłego wieku. Kolejną przyczynę, związaną z poprzednią i być może najważniejszą, stanowi próba unieważnienia kataryzmu jako przedmiotu badań podjęta przez przedstawicieli podejścia krytycznego w historiografii katarskiej. Badacze tego nurtu podważają adekwatność nazwy „katarzy” dla grup średniowiecznych dysydentów religijnych działających w Nadrenii, Italii i Langwedocji, wątpią w dualistyczną doktrynę wspomnianych wspólnot religijnych i w końcu negują istnienie rozległej i zhierarchizowanej organizacji Kościoła katarskiego. O temperaturze dyskusji podnoszonej nie tylko przez zapał polemiczny jej uczestników, lecz także przez świadomość wagi zagadnienia, niech zaświadczy wypowiedź jednego z jej bohaterów:

\footnotetext{
1 Por. J. Borkowska, Kataryzm. Spór o dualizm średniowieczny, Kraków 2006, Nomos. 2 Por. M. Dobkowski, Kataryzm. Historia i system religijny, Kraków 2007, WAM. 3 Por. P. Czarnecki, Kataryzm wtoski. Historia i doktryna, Kraków 2013, Nomos, (pozycja omówiona w części Historiografia tradycyjna artykułu).
} 
Jest godne pożałowania, że dzisiejsi uczeni posługują się tą nazwą [„katar” M. D.] z tak rażącym brakiem orientacji; rzuca się ją beztrosko jak konfetti, z lenistwa przyklejając do niemal wszystkich heretyków sprzed XIV wieku, aż stała się epitetem bardziej mylącym niż klasyfikującym. ${ }^{4}$

Nie jest moim zamiarem rozstrzygnięcie w niniejszym artykule wspomnianego sporu historiograficznego, który jest zarazem szczegółowy i wielopłaszczyznowy, dotyczy tyleż źródeł, co metodologii, a ponadto przyciąga uwagę badaczy pochodzących z kilku krajów. Stawiam sobie cel mniej ambitny. Chciałbym, zarysowując stanowiska stron dyskusji o dysydencji katarskiej i ukazując ich argumenty, przedstawić możliwie wyraźnie sytuację historiograficzną w nadziei, że ułatwi to historykom podejmowanie tematu kataryzmu i kontestacji religijnej w średniowieczu.

Moja analiza obejmie literaturę naukową dotyczącą dysydencji katarskiej wydaną po 1990 r., choć niekiedy cezurę tę będę przesuwał w przeszłość, ale tylko wtedy, gdy omawiany tekst wywierał wpływ na historiografię ostatniego ćwierćwiecza. Taki zakres chronologiczny został podyktowany tym, że we wspomnianym okresie ujawniły się wyraźnie wszystkie aktualne dziś ujęcia i nurty badawcze. Prezentację określonej postawy historiograficznej poprzedzę wzmiankami o prekursorach, założycielach albo najlepszych wyrazicielach danego nurtu, publikujących przed analizowanym przeze mnie etapem rozwoju badań nad kontestacją katarską, aby z takiej perspektywy lepiej pokazać współczesne sposoby myślenia o tym zjawisku historycznym i religijnym. Oczywiście, umieszczanie historyków i ich prac w określonych nurtach badawczych i przypisywanie im pewnych stanowisk teoretycznych jest czynnością także subiektywną, a więc i dyskusyjną, jednak - jak sądzę - potrzebną, bo ułatwiającą orientację w literaturze przedmiotu.

W prezentowanym tekście pominąłem ważny kierunek badań nad kataryzmem, rozwijający się od lat siedemdziesiątych ubiegłego wieku, którego przedmiot można nazwać „kataryzmem w kontekstach pozahistoriograficznych” lub „kataryzmem zmitologizowanym”

\footnotetext{
4 M. G. Pegg, Najświętsza wojna. Krucjata przeciwko albigensom i bój o chrześcijaństwo, tł. J. Szczepański, Poznań 2010, Rebis, s. 55.

5 Chodzi tu o następne zagadnienia szczegółowe: polemika katolicko-protestancka okresu Reformacji, regionalna tożsamość okcytańska w XIX i XX w., ideologia i polityka w XIX i XX w., literatura piękna, poszukiwania okultystyczno-ezoteryczne oraz współczesna kultura masowa.
} 
pierwsze dlatego, że nie odnosi się on bezpośrednio do średniowiecza, a po drugie z tego powodu, że problematykę tę dobrze omówiła ostatnio Marta Höffner ${ }^{6}$. Ponieważ w niniejszym artykule piszę o historiografii dysydencji katarskiej tylko w odniesieniu do ostatnich 25 lat, jako uzupełnienie zamieszczam w aneksie wybraną bibliografię prac na jej temat uwzględniającą i krótko charakteryzującą także wcześniejsze publikacje .

I. Historiografia tradycyjna

Współczesne naukowe badania nad średniowieczną dysydencją religijną nazywaną kataryzmem, a także ujęcie badawcze określane przeze mnie tu jako „tradycyjne”, zapoczątkował Charles Schmidt ${ }^{8}$, luterański teolog i historyk Kościoła, który całe swoje życie związał ze Strasburgiem. Wyniki badań na temat katarów zawarł w pracy wydanej w 1849 r. pt. Histoire et doctrine de la secte des Cathares ou Albigeois ${ }^{9}$. W jego epoce nie odkryto jeszcze świadectw pochodzenia katarskiego, nie mógł więc z nich korzystać, natomiast w skład bazy źródłowej alzackiego historyka weszły wszystkie inne ówcześnie znane świadectwa, czyli zarówno te autorów Kościoła katolickiego, jak i te, które, choć pochodzenia niekatarskiego, były używane przez katarów (apokryfy Interrogatio Iohannis oraz Visio Isaiae).

Swoje dzieło Schmidt podzielił na trzy zasadnicze części umieszczone w dwóch tomach. W pierwszym znalazła się „historia sekty”, natomiast w drugim - „doktryny i moralność” oraz „,rzut oka na środki zastosowane w celu wykorzenienia herezji katarskiej i herezji w ogóle". Skupię się tutaj na dwóch pierwszych częściach jako podstawowych dla omawianej pracy i prezentowanego przeze mnie zagadnienia.

Jeśli chodzi o początki kataryzmu, badacz zakładał, że zachodni katarzy i wschodni bogomiłowie pochodzili od jakiejś grecko-słowiańskiej wspólnoty religijnej, która działała w Bułgarii od początku wieku X. Jej

\footnotetext{
6 Por. M. Höffner, Kataryzm - między mitem a historia, „Studia Religiologica”, 41, 2008, s. 201-215.

7 Zob. Aneks.

8 Na temat Ch. Schmidta i jego dzieła zob. przede wszystkim: Y. Dossat, Un initiateur: Charles Schmidt, „Cahiers de Fanjeaux”, 14, 1979: Historiographie du catharisme, s. 163184; B. Hamilton, The State of Research. The Legacy of Charles Schmidt to the study of Christian dualism, "Journal of Medieval History”, 24, 1998, s. 191-214.

9 Por. Ch. Schmidt, Histoire et doctrine de la secte des Cathares ou Albigeois, t. 1-2, Paris-Genève 1849.
} 
pierwotną doktryną był radykalny dualizm, a odmiana umiarkowana powstała dopiero później, pod wpływem euchitów/mesalian ${ }^{10}$. Odrzucił jednak tezę, jakoby katarzy byli kontynuatorami starożytnych manichejczyków $^{11}$, a nawet późniejszych paulicjan ${ }^{12}$. W dziejach badanej formacji religijnej Schmidt wyróżnił trzy główne okresy: pierwszy, od końca X do połowy XII w., gdy dualiści docierają do Europy Zachodniej ${ }^{13}$; drugi, do przełomu XII/XIII w., kiedy katarzy organizują się i działają otwarcie ${ }^{14}$, oraz trzeci, do połowy XV w., w którym kataryzm długo wygasa ${ }^{15}$. Obszar geograficzny badań zakreślił bardzo szeroko: zaliczył do niego kraje bałkańskie, Włochy, południe i północ Francji, Niemcy, Anglię i Hiszpanię.

System religijny zachodniej dysydencji dualistycznej został przedstawiony w omawianej pracy według następujących zagadnień: doktryna ${ }^{16}$, moralność i dyscyplina ${ }^{17}$, kult $^{18}$ oraz organizacja kościelna ${ }^{19}$. Opis doktryny katarów podporządkowano dwóm rodzajom dualizmu: radykalnemu i umiarkowanemu. W zależności od tego, czy dwie zasady, dobra i zła, są równorzędne, czy zła, chociaż autonomiczna, jest jednak zależna od dobrej, przedstawiane są inne aspekty wiary zachodnich dualistów. Człowiek według katarów - twierdził alzacki historyk - jest aniołem zamkniętym przez złego boga lub diabła w materialnym ciele. Schmidt zwrócił także uwagę na doketyzm chrystologiczny zachodnich dualistów, uważał ponadto, że, według nich, misja Chrystusa polegała na przyniesieniu uwięzionym w ciele duszom wiedzy o ich prawdziwym, niebiańskim, pochodzeniu oraz innych środków zbawczych (np. pokuty). Jeśli chodzi o moralność i dyscyplinę religijną omawianej dysydencji, to Schmidt zauważył istnienie dwóch kodeksów etycznych wyznawców: ascetycznego - doskonałych i znacznie łagodniejszego - wierzących. Omawiając przejawy kultu, koncentrował się na chrzcie duchowym (consolamentum), błogosławieniu chleba oraz wyznaniu grzechów. I wreszcie, jeśli chodzi

\footnotetext{
10 Por. ibidem, t. 1, s. 1-15.

11 Por. ibidem, t. 2, s. 252-261.

12 Por. ibidem, t. 2, s. 261-263.

13 Por. ibidem, t. 1, s. 1-54.

14 Por. ibidem, t. 1, s. 54-99.

15 Por. ibidem, t. 1, s. 99-379.

16 Por. ibidem, t. 2, s. 8-78.

17 Por. ibidem, t. 2, s. 79-100.

18 Por. ibidem, t. 2, s. 110-139.

19 Por. ibidem, t. 2, s. 139-150.
} 
o organizację kościelną zachodnich dualistów, zwracał uwagę na jej hierarchiczność (biskupi i diakoni) oraz stosunkowo rozległą i spójną strukturę terytorialną składającą się z diecezji i diakonatów.

Charles Schmidt w swojej refleksji nad istotą dysydencji katarskiej podkreślał wyraźny rozziew pomiędzy dualistyczną doktryną katarów a chrześcijaństwem. Twierdził on, że - mimo częstego odwoływania się przez zachodnich dualistów do Nowego Testamentu - odnosi się silne wrażenie, iż to źródło nauki chrześcijańskiej zostało dość arbitralnie zaadaptowane do doktryny religijnej katarów, która swój początek miała poza chrześcijaństwem.

\section{Główny nurt historiografii tradycyjnej}

W analizowanym przeze mnie etapie rozwoju historiografii dysydencji katarskiej, to jest od początku lat dziewięćdziesiątych ubiegłego wieku do dzisiaj, badacze znajdują się w innej sytuacji pod względem bazy źródłowej niż Charles Schmidt, przede wszystkim dlatego, że dysponują już świadectwami pochodzenia katarskiego. Obserwacja ta dotyczy oczywiście zarówno historyków preferujących ujęcie tradycyjne, jak i krytyczne.

Za najważniejszego przedstawiciela głównego nurtu historiografii tradycyjnej omawianego przeze mnie okresu można uznać południowofrancuskiego badacza Jeana Duvernoy'a. Jego najbardziej znacząca pracą jest dwutomowa synteza Le catharisme ${ }^{20}$, wydana w latach siedemdziesiątych i wznowiona pod koniec następnej dekady. Książka ta wywierała silny wpływ na kształtowanie się obrazu zachodnich dualistów w literaturze przedmiotu także w latach dziewięćdziesiątych. Duvernoy, opisując dzieje dysydencji katarskiej w tomie drugim swojej pracy, łączy ją ściśle z bogomilizmem, a rekonstruowanie jej historii rozpoczyna od studiów nad pierwszymi wzmiankami na temat kontestacji religijnych na Zachodzie w wieku XI. Poza tym, chociaż widzi działalność dualistów, tak jak Schmidt, w całej Zachodniej Europie, to szczególnie dużo miejsca poświęca w tym względzie Langwedocji. Z kolei w tomie pierwszym, dotyczącym aspektu religijnego kataryzmu, przedstawia on źródła wiary wyznawców tej formacji religijnej, doktrynę z uwzględnieniem różnych jej wariantów oraz praktykę religijną i organizację kościelną. Autor nie

20 Por. J. Duvernoy, Le catharisme, t. 1: La religion des cathares, Toulouse 1976, Privat (II wyd. 1989; wyd. polskie: Religia katarów, tł. J. Górecka-Kalita, Kraków 2000, Platan); idem, Le catharisme, t. 2: L'histoire des cathares, Toulouse 1979, Privat (II wyd. 1989). 
pomija również kontekstu społecznego i kulturowego omawianej dysydencji, a także bada mniej lub bardziej prawdopodobne filiacje kataryzmu $\mathrm{z}$ innymi formacjami religijnymi. W zakończeniu tomu przedstawiającego kwestie religijne dysydencji katarskiej południowofrancuski historyk mówi o wspólnocie bogomilsko-katarskiej, cechującej się tą samą praktyką religijną, ale zróżnicowanej pod względem dualistycznej doktryny, o wspólnocie, której kolebką były prawdopodobnie tereny Macedonii. Twierdzi ponadto - w przeciwieństwie do Schmidta - że dualistyczna nauka bogomiłów i katarów nie została przyniesiona z zewnątrz, tylko wypracowana przez dysydentów na podstawie Nowego Testamentu i apokryfów. Uważa on zatem katarów za chrześcijan i to o wyraźnym odcieniu orygenistycznym, odrzuca ponadto ich powiązania historyczne z gnostykami, marcjonitami, manichejczykami i pryscylianami, podkreślając, jak wspominałem, silny związek zachodnich dualistów z bogomiłami ${ }^{21}$.

Kolejnym reprezentantem podejścia tradycyjnego w historiografii dysydencji katarskiej jest inny badacz z południa Francji: Michel Roquebert. Wydał on L'épopée cathare, pięciotomowe dzieło na temat dziejów dualistycznych kontestatorów religijnych w Langwedocji, pisane przez prawie trzydzieści lat (1970-98), które zostało ostatnio wznowione jako wydanie całościowe i poprawione ${ }^{22}$. W 2001 r. opublikował także La religion cathare, gdzie bada kataryzm jako zjawisko czysto religijne, tj. poza kontekstem społecznym i politycznym ${ }^{23}$. W książce tej rekonstruuje naukę religijną katarskich dysydentów prawie wyłącznie na podstawie źródeł ich własnego autorstwa. Dla Roqueberta kataryzm - choć do tej nazwy zachodniej dysydencji dualistycznej odnosi się dość ostrożnie - jest zjawiskiem, które można uchwycić z pewnością dopiero od drugiej połowy XII w. w Langwedocji i we Włoszech. Według tego autora, identyfikacja zachodniej kontestacji religijnej od roku tysięcznego do połowy XII w. sprawia dużą trudność. Pojawiające się wówczas ruchy religijne można uznać za skutek misyjnej działalności bogomiłów, ale także - za efekt spontanicznej kontestacji ewangelicznej, w której Kościół rzymski pragnął widzieć jednolitą herezję ${ }^{24}$. Co do pochodzenia dysydencji katarskiej, południowofrancuski historyk uważa ją za fenomen chrześcijański,

21 Por. J. Duvernoy, Le catharisme, t. 1, s. 387-390 (tu i dalej strony za wyd. z 1989 r.).

22 Por. M. Roquebert, L'épopée cathare, t. 1-5, Paris 2006-2007, Perrin.

23 Por. M. Roquebert, La religion cathare. Le Bien, le Mal et le Salut dans l'hérésie, Paris 2001, Perrin (wyd. popr.: Paris 2009).

24 Por. ibidem, s. 11-41. 
opierający się na Nowym Testamencie. Bierze ponadto w nawias rozważania na temat wcześniejszych formacji religijnych oraz ich wpływu na kataryzm (i bogomilizm), twierdzi bowiem, że wyrasta on z tego samego doświadczenia religijnego, co starożytny gnostycyzm ${ }^{25}$.

Do przedstawicieli omawianego nurtu historiografii należy zaliczyć także autorów brytyjskich: Malcolma Lamberta i Malcolma Barbera. Pierwszy opublikował w 1998 r. syntezę dziejów ruchu katarskiego pt. The Cathars ${ }^{26}$. W pracy tej zajmuje się on przede wszystkim historia dysydencji katarskiej, w mniejszym stopniu odnosząc się do zagadnień stricte religijnych. Kreśli on szeroką panoramę herezji katarskiej w Zachodniej Europie, najwięcej miejsca poświęcając Langwedocji i Włochom, ale wspomina także o Kościele bośniackim na Bałkanach. Lambert podkreśla duże podobieństwo pomiędzy bogomilizmem i kataryzmem oraz dowodzi wpływu pierwszego na drugi ${ }^{27}$. Nie wyklucza również pewnego oddziaływania paulicjan na bogomiłów ${ }^{28}$. Z kolei Malcolm Barber w swoim studium The Cathars. Dualist Heretics in Languedoc in the High Middle Ages ${ }^{29}$ z 2000 r. przedstawia dzieje dysydencji katarskiej na tle społeczeństwa południowej Francji i omawia funkcjonowanie tam Kościoła katarskiego. Przyjmuje on tezę o wpływie Kościoła bogomilskiego na kataryzm, podaje jednak w wątpliwość możliwość ustalenia powiązań z wcześniejszymi formami dualizmu ${ }^{30}$.

2. Dysydencja katarska jako zjawisko pochodzenia zewnętrznego (nurt egzogeniczny) Autorzy prezentowanego tu nurtu historiografii tradycyjnej nie wahaja się podkreślać nie tylko ścisłych związków dysydencji katarskiej z bogomilską, ale sięgają znacznie dalej w przeszłość, aby ukazać długi rodowód zachodnich dualistów.

Za najlepszego wyraziciela nurtu egzogenicznego ujęcia tradycyjnego można uznać brytyjskiego historyka Stevena Runcimana. W swojej pracy

\footnotetext{
25 Por. ibidem, s. 359-368.

26 Por. M. D. Lambert, The Cathars, Oxford 1998, Blackwell.

27 Por. ibidem, s. 23-37.

28 Por. ibidem, s. 56.

29 Por. M. Barber, The Cathars. Dualist Heretics in Languedoc in the High Middle Ages, Harlow 2000, Longman (wyd. polskie: Katarzy, tł. R. Sudół, Warszawa 2004, PIW).

30 Por. M. Barber, Katarzy, s. 14.
} 
The Medieval Manichee ${ }^{31}$ z 1947 r. odtworzył on łańcuch historycznych powiązań między średniowiecznym kataryzmem a późnostarożytnym gnostycyzmem. Wyglądał on następująco: gnostycym, który nawiązywał do rozmaitych idei dualistycznych i antyświatowych, podzielił się na dwa prądy: dualistyczny (głównie manichejczycy) i monarchiański. Pierwszy zainspirował paulicjan i wraz z nimi dotarł na Bałkany, drugi natomiast uległ wpływowi mesalian oraz montanistów i również znalazł swoje miejsce na Bałkanach. Na tym obszarze oba prądy połączyły się, tworząc bogomilizm, a ten z kolei zapoczątkował kataryzm. Brytyjski badacz podkreślił jednak mimo wszystko chrześcijański charakter tej dualistycznej tradycji ${ }^{32}$. Orientacja historiograficzna, której przedstawicielem był Runciman, odgrywała ważną rolę w latach czterdziestych i pięćdziesiątych ubiegłego wieku i określano ją neomanichejską ${ }^{33}$.

W badanym przeze mnie okresie omawiana orientacja badawcza ma wciąż swoich reprezentantów. Jednym z nich jest Bernard Hamilton, który wraz z Janet Hamilton w 1998 r. wydał tłumaczenia źródeł do dziejów paulicjan i bogomiłów ${ }^{34}$. W obszernym wstępie do tego zbioru autorzy nazywają dwie wspomniane wschodnie formacje dualistyczne oraz zachodnich katarów „chrześcijańskimi dualistami średniowiecza”. Twierdzą ponadto, że owi „chrześcijańscy dualiści” nie byli ani spadkobiercami gnostyków, ani manichejczyków, chociaż dopuszczają pewne wpływy zaratusztrianizmu na paulicjanizm i przyznają, iż chrześcijańscy dualiści mieli dostęp do pism gnostyckich ${ }^{35}$.

31 Por. S. Runciman, The Medieval Manichee. A Study of the Christian Dualist Heresy, Cambridge 1947 (wyd. polskie: idem, Manicheizm średniowieczny, tł. J. Prokopiuk, B. Zborski, Gdańsk 1996, Marabut).

32 Por. S. Runciman, Manicheizm średniowieczny, s. 164-165, 169.

33 Zob.: E. Delaruelle, L'état actuel des études sur le catharisme, „Cahiers de Fanjeaux”, 3: Cathares en Languedoc, 1968, s. 34-36; P. Jiménez-Sanchez, La vision médiévale du catharisme chez les historiens des annees 1950: un néo-manicheisme, [w:] Catharisme: édifice imaginaire. Actes du 7 e colloque du Centre d'Étude Cathares/René Nelli, Carcassonne, 29 aồt-2 septembre 1994, dir. J. Berlioz, J.-C. Hélas, Carcassonne 1998, Centre d'étude cathares, s. 65-96.

34 Por. J. i B. Hamilton, Christian Dualist Heresies in The Byzantine World c. 650-c. 1405, Manchester 1998, Manchester UP.

35 Por. ibidem, s. 1-5, 8. 
Innym zwolennikiem hipotezy o zewnętrznym pochodzeniu dysydencji katarskiej jest Yuri Stoyanov. Badacz ten w książce The Other God z 2000 r. ${ }^{36}$ ukazuje niezwykle długą perspektywę tradycji dualistycznej od zaratusztrianizmu (a nawet od pewnych wątków religii egipskiej) po kataryzm. Powstanie określonej formacji dualistycznej jest dla niego wypadkową wspomnianego przekazu i warunków religijnych panujących w określonym miejscu i czasie. Autor ma jednak świadomość, z jednej strony, nie tylko kontynuacji, lecz także zerwań pomiędzy składowymi tej tradycji (np. między paulicjanami a bogomiłami), z drugiej zaś - tendencji do posługiwania się przez autorów źródeł polemicznych schematyzującymi etykietami (stereotypowe oskarżenia o manicheizm), co utrudnia badaczom identyfikację poszczególnych grup heretyckich.

W tym miejscu trzeba też powiedzieć o obszernym studium młodego polskiego historyka Piotra Czarneckiego pt. Kataryzm wtoski (2013) ${ }^{37}$. Książka ta być może najlepiej mieści się w założeniach prezentowanego nurtu, gdyż inne prace tej orientacji skupiają się przede wszystkim na powiązaniach między poszczególnymi formacjami dualistycznymi, kataryzm traktując tylko jako jeden z elementów tradycji. Dla Czarneckiego natomiast katarzy są wyraźnym punktem docelowym wcześniejszych ruchów dualistycznych. Zewnętrznym źródłom dysydencji katarskiej, paulicjanizmowi i bogomilizmowi, autor poświęca pierwszy rozdział swojej książki ${ }^{38}$, w drugim mówi o jej początkach we Włoszech i w zachodniej Europie $^{39}$, a w czterech następnych - o głównym przedmiocie swoich zainteresowań, czyli o katarach włoskich ${ }^{40}$. Początek chrześcijańskiej tradycji dualistycznej polski badacz upatruje we wspólnocie paulicjan założonej około połowy VII w. na pograniczu bizantyjsko-arabskim, której doktryna została stworzona przez Konstantyna z Mananalis w wyniku „schrystianizowania” doktryny manichejskiej. Z kolei bogomilizm miał powstać dzięki twórczemu połączeniu paulicjanizmu z mesalianizmem, dysydencja katarska zaś narodziła się pod wyraźnym wpływem bogomilizmu. Jeśli chodzi o rozprzestrzenianie się wpływów bogomilskich w Europie Zachodniej i powstawanie wspólnot katarskich, Czarnecki,

36 Por. Y. Stoyanov, The Other God. Dualist Religion from Antiquity to the Cathar Heresy, New Haven 2000, Yale UP.

37 Por. P. Czarnecki, op. cit.

38 Por. ibidem, s. 19-96.

39 Por. ibidem, s. 97-171.

40 Por. ibidem, s. 173-434. 
opierając się głównie na pochodzącym z drugiej połowy XIII w. tekście Tractatus de hereticis autorstwa inkwizytora Anzelma z Alessandrii, twierdzi, że nauka dualistyczna (w wersji umiarkowanej) została przekazana na Zachód nie przez wysłanników bogomilskich, ale przez łacinników, którzy zostali nawróceni na nią przez bogomiłów w Konstantynopolu. Misje wschodnich dualistów pojawiły się na Zachodzie w dwóch falach: w pierwszej połowie XI w. i w połowie XII stulecia. Innym wydarzeniem istotnym dla formowania się kataryzmu był synod w Saint-Félix-de-Caraman w 1167 r., gdzie przybyły z Konstantynopola bogomilski biskup Niketas dokonał próby nawrócenia zachodnich dualistów na doktrynę radykalną. Podstawowy temat książki, dzieje kataryzmu włoskiego, dobrze ukazuje, jak pochodzące z zewnątrz idee i formy życia religijnego wchodzą w skomplikowane relacje z nowym środowiskiem religijno-społecznym. W Italii wyraźnie modyfikuje się bogomilska doktryna dualistyczna, rozwijana na dwa sposoby: w paradygmacie mitycznym (pojawiają się nowe wątki mityczne) i racjonalnym (prawdy dualistyczne prezentowane są na sposób teologiczno-filozoficzny). Niewiele zmienia się natomiast liturgia, etyka i organizacja. Autor podkreśla zatem, że w wyniku tych przeciwstawnych procesów pogłębiał się dystans między elitą religijną (zainteresowaną doktryna) i zwykłymi wiernymi (pokładającymi nadzieję w praktyce). Dodać należy, że Piotr Czarnecki w swojej książce zdecydowanie przeciwstawia się endogenicznemu nurtowi tradycyjnej historiografii, szkoda natomiast, że nie odnosi się do argumentów historiografii krytycznej ${ }^{41}$.

3. Dysydencja katarska jako zjawisko biorące swój początek z chrześcijaństwa łacińskiego (nurt endogeniczny)

Prekursorem nurtu historiografii tradycyjnej, podkreślającego endogeniczne pochodzenie dysydencji katarskiej, nurtu, który zaczą się rozwijać dopiero w latach osiemdziesiątych i dziewięćdziesiątych XX w., był włoski badacz Raffaello Morghen ${ }^{42}$. W połowie ubiegłego wieku swoje

${ }^{41}$ Zob. też M. Dobkowski, [art. rec.] P. Czarnecki, Kataryzm wtoski. Historia i doktryna, „Studia Religiologica”, 46, 2013, s. 327-334.

42 Na temat poglądów Morghena zob.: G. Gonnet, Les débuts en Italie de l'historiographie des hérésies médiévales, „Heresis”, 21, 1993, s. 112-115; P. Jiménez-Sanchez, Les catharismes. Modèles dissidents du christianisme médiéval (XIIe-XIIIe siècles), Rennes 2008, Presses Universitaires de Rennes, s. 32-33; J.-Ph. Marcoux-Fortier, „Ritus hereticorum”. 
stanowisko zaprezentował w obszernym artykule Osservazioni critiche su alcune questioni fondamentali riguardanti le origini e $i$ caratteri delle eresie medioevali ${ }^{43}$ oraz w książce Medioevo cristiano $^{44}$, a podsumował na kongresie w Royaumont w 1962 r., poświęconym herezjom w społeczeństwie średniowiecznym i nowożytnym ${ }^{45}$. W wystąpieniu w Royaumont Morghen sprzeciwił się łączeniu pierwszych herezji zachodniej Europy (XI w.) „ze starożytną doktryną manichejską”, stwierdzając przy tym, że o rzeczywistych związkach między zachodnimi dysydentami a tymi z Bałkanów można mówić dopiero od wieku XII. Dopiero wówczas daje się też odnaleźć pewne odniesienia do starożytnych tradycji heterodoksyjnych. Początek i naturę zachodniej dysydencji religijnej widział on w postawie protestu przeciw nadużyciom Kościoła rzymskiego i w tęsknocie do Kościoła apostolskiego pierwszych wieków. Doktryny głoszone przez kontestatorów religijnych miały powstawać pod wpływem spontanicznej lektury Ewangelii i z inspiracji ideału życia monastycznego, a za pośrednictwem wędrownych kaznodziejów miały znaleźć swoich zwolenników wśród niewykształconych, świeckich warstw społeczeństwa. W opinii Morghena również bogomilizm był w pierwszym rzędzie ruchem antyklerykalnego protestu, który pojawił się w środowisku Kościoła bizantyjskiego niezależnie od omawianego zjawiska w Kościele łacińskim. Włoski historyk przyczyn narodzin zachodniej dysydencji religijnej XI w. upatrywał w dynamice procesów demograficznych, gospodarczych i społecznych (wzrost demograficzny, migracja ze wsi do miast, zwiększenie wydajności rolnictwa, odrodzenie handlu i wymiany pieniężnej), które prowadziły do przemian w mentalności indywidualnej i zbiorowej. A zatem, wartość propozycji Morghena polegała przede wszystkim na podkreśleniu znaczenia rodzimych inspiracji dla średniowiecznej kontestacji religijnej na Zachodzie (dążenie do odnowienia kościoła, przewaga

Les rites de l'hérésie des „bons hommes” comme construction cléricale au sein de deux registres d'Inquisition (Albi, 1286-1287 et 1299-1300), Québec 2011, Université Laval, s. 13-16 (wersja elektroniczna: http://theses.ulaval.ca/archimede/fichiers/27725/27725.pdf; dostęp: 04.04.2014).

43 Por. R. Morghen, Osservazioni critiche su alcune questioni fondamentali riguardanti le origini e i caratteri delle eresie medioevali, „Archivio della Società Romana di Storia Patria”, 67, 1944, s. 97-151.

44 Por. R. Morghen, Medioevo cristiano, Bari 1951, Laterza.

45 Por. R. Morghen, Problèmes sur l'origine de l'hérésie au Moyen Âge, [w:] Hérésies et sociétés dans l'Europe pré-industrielle (11e-18e siècles). Actes du colloque de Royaumont de 1962, dir. J. Le Goff, Paris 1968, Mouton, s. 121-138. 
postulatów moralnych nad doktrynalnymi, Ewangelia jako źródło nauk dysydenckich), a także na umieszczeniu tego zjawiska religijnego w lokalnym kontekście zmian społecznych i gospodarczych.

Omawiana tu orientacja historiograficzna w badanym przeze mnie okresie jest reprezentowana przede wszystkim przez dwie południowofrancuskie badaczki: Anne Brenon i Pilar Jiménez-Sanchez. Pierwsza z nich zaprezentowała swoje stanowisko na przełomie lat osiemdziesiątych i dziewięćdziesiątych ubiegłego wieku w książce Le vrai visage du catharisme $e^{46}$ oraz w artykule Les hérésies de l'An Mil. Nouvelles perspectives sur les origines du catharisme ${ }^{47}$; Brenon $\mathrm{w}$ Le vrai visage pojmuje dysydencję katarska, opisywaną przede wszystkim w jej odmianie langwedockiej, jako grupę Kościołów katarskich odczytujących Nowy Testament na sposób dualistyczny i odwołujących się do ideału ewangelicznego ubóstwa. Podkreśla ona zróżnicowanie doktryny katarskiej i jej podatność na modyfikacje: uczony nurt katarów włoskich rozwijał się pod wpływem scholastyki i arystotelizmu, podczas gdy pasterze langwedoccy, reprezentujący religijność ludową, tworzyli narracje na temat reinkarnacji. Pod względem organizacji i liturgii Kościół katarski, według autorki, bardzo wyraźnie nawiązywał do wspólnoty pierwszych chrześcijan. Jeśli chodzi o pochodzenie dysydencji katarskiej, południowofrancuska badaczka umieszcza ją wyraźnie w kontekście dążeń do ewangelicznej odnowy Kościoła łacińskiego w wiekach XI i XII. Odrzuca ona możliwość wcześniejszych powiązań manichejsko-paulicjańskich i paulicjańsko-bogomilskich, a nawet minimalizuje prawdopodobieństwo wpływu bogomiłów na dualistów łacińskich, twierdząc, że „katarzy i bogomiłowie byli raczej kontynuatorami tego samego ruchu historycznego" ${ }^{48}$. We wspomnianym przeze mnie artykule Brenon podtrzymuje przekonanie, że bogomilizm i kataryzm są dwiema odmianami (grecką i łacińską) tej samej chrześcijańskiej dysydencji.

46 Por. A. Brenon, Le vrai visage du catharisme, Portet-sur-Garonne 1988, Loubatières (wyd. przejrzane i poprawione: 2008).

47 Por. A. Brenon, Les hérésies de l'An Mil. Nouvelles perspectives sur les origines du catharisme, „Heresis”, 24, 1995, s. 21-36.

48 A. Brenon, Le vrai visage, s. 95 (strony za wyd. z 1988). 
Także obszerną syntezę Pilar Jiménez-Sanchez Les catharismes ${ }^{49}$ należy zaliczyć do nurtu endogenicznego. Autorka odrzuca tu tezę o zewnętrznym, wschodnim, pochodzeniu dysydencji katarskiej na rzecz zachodniej inspiracji nie tylko ewangelicznej, ale i teologicznej. Książka ta z powodu odniesień historiograficznych, obszernej i dokładnie analizowanej bazy źródłowej oraz uwzględnienia tez historiografii krytycznej wymaga osobnego omówienia w innym już miejscu.

\section{Podsumowanie}

Podsumowując badania nad dysydencją katarską mieszczące się w ujęciu tradycyjnym, trzeba powiedzieć, że kataryzm postrzegany jest tutaj jako realne zjawisko historyczne o wyraźnej tożsamości. Historycy reprezentujący wspomnianą postawę badawczą w ostatnim ćwierćwieczu twierdzą zgodnie, że dysydencja katarska charakteryzowała się pod względem doktryny przede wszystkim dualizmem, który przenikał (z większą czy mniejszą siła) teologię, kosmologię i antropologię. Wskazują też inne cechy: doketyzm w chrystologii, a w antropologii - przekonanie, że człowiek jest aniołem zamkniętym w materialnym ciele. Akcentują również powszechne posługiwanie się przez dysydentów katarskich Nowym Testamentem do uzasadniania ich prawd wiary. Badacze podkreślają niechęć katarów do kościoła rzymskiego i jego sakramentów, a jednocześnie odtwarzają oryginalną liturgię katarów z chrztem duchowym (consolamentum) na czele. Historycy zwracają także uwagę na dwie klasy wyznawców o różnych kodeksach etycznych oraz na hierarchiczne wspólnoty-kościoły katarskie, tworzące swego rodzaju konfederację.

W omawianym okresie badań nad dysydencją katarską najważniejszą kwestią dzielącą uczonych podejścia tradycyjnego jest pochodzenie omawianego zjawiska. Badacze nurtu głównego podkreślają wpływ bogomiłów na katarów i zasadniczo podważają możliwość ustalenia powiązań z wcześniejszymi formacjami dualistycznymi. Historycy orientacji egzogenicznej podtrzymują tezę (chociaż zdecydowanie słabiej formułowaną niż w latach czterdziestych i pięćdziesiątych XX w.) o możliwości jakichś pośrednich oddziaływań na katarów ze strony formacji antycznych, takich jak zaratusztrianie, gnostycy czy manichejczycy. Autorzy ci są jednak zwykle świadomi transformacji, którym ulegały doktryny i praktyki religijne

49 Por. P. Jiménez-Sanchez, Les catharismes. Modèles dissidents du christianisme médiéval (XIIe-XIIIe siècles), Rennes 2008, Presses Universitaires de Rennes. 
w nowych środowiskach, a także kłopotów ze źródłami, wynikających $\mathrm{z}$ ich braku lub tendencyjności. Ważnym i płodnym poznawczo novum jest wprowadzenie kategorii „chrześcijaństwo dualistyczne” na określenie paulicjanizmu, bogomilizmu i kataryzmu. Wreszcie badacze nurtu endogenicznego akcentują zachodnie pochodzenie dysydencji katarskiej, powstałej w związku z nową religijnością pełnego średniowiecza (i bagatelizują rolę bogomilizmu, który miał być, według nich, równoległym do kataryzmu procesem w kościele bizantyjskim). Jeśli chodzi o czas narodzin kataryzmu, badacze historiografii tradycyjnej ostatniego ćwierćwiecza wskazują tu zasadniczo na połowę wieku XII.

Trzeba też dodać, że chociaż historycy reprezentujący podejście tradycyjne uważają dysydencję katarską za zjawisko stricte chrześcijańskie, to jednak niektórzy z nich zwracają uwagę na transhistoryczne doświadczenie religijne, które mogło być wspólne dla różnych formacji dualistycznych i gnostycznych.

\section{Historiografia krytyczna}

(dekonstrukcjonistyczna)

Jako prekursorów historiografii krytycznej (dekonstrukcjonistycznej) wymienia się zwykle Raffaello Morghena, część badaczy uczestniczących we wspominanej już konferencji w Royaumont w 1962 r. oraz angielskiego historyka Roberta I. Moore'a ${ }^{50}$. Wpływ Morghena na powstanie podejścia dekonstrukcjonistycznego polegał przede wszystkim na zaakcentowaniu spontanicznej duchowości ewangelicznej po roku tysięcznym w Europie Zachodniej. Ale obserwacje tego historyka były także punktem wyjścia dla myślenia o herezji jako spójnej konstrukcji erudycyjnej i instytucjonalnej nakładanej na słabo ustrukturyzowane i ludowe zjawiska religijno-spo$ł^{\prime} \mathrm{l} \mathrm{e}^{51}$. Na problemie powstawania herezji skupił się na konferencji w Royaumont polski mediewista Tadeusz Manteuffel. Stwierdził on, że określona mniejszość ideologiczna stawała się herezją w wyniku decyzji władz kościelnych, uzależnionej od tego, czy przedstawiciele danej dysydencji wykazywali się posłuszeństwem czy niesubordynacją wobec

\footnotetext{
50 Na temat historiografii krytycznej zob.: M. Roquebert, Le „déconstructionisme” et les études cathares, [w:] Les cathares devant l'histoire. Mélanges offerts à Jean Duvernoy, dir. M. Aurell, Cahors 2005, L'Hydre, s. 105-133; J.-L. Biget, Hérésie et inquisition dans le midi de la France, Paris 2007, Picard, s. 73, 76-80; P. Jiménez-Sanchez, Les catharismes, s. 43-46; J.-Ph. Marcoux-Fortier, „Ritus hereticorum”, s. 21-26.

51 Por. R. Morghen, Problèmes sur l'origine, s. 123-124.
} 
Kościoła $^{52}$. Nierozerwalność połączenia ortodoksja-herezja podkreślił też Georges Duby w podsumowaniu wspomnianej debaty ${ }^{53}$. Z kolei Robert I. Moore w książce The Formation of a Persecuting Society $(1987)^{54}$ przedstawił teorię społeczeństwa wykluczającego i prześladującego, które powstawało w Europie Zachodniej pomiędzy wiekiem X a XIII. Pokazał on, jak władze duchowne i świeckie stopniowo tworzyły jednolity i sztuczny obraz społecznego wroga, który został utożsamiony z różnymi mniejszościami, takimi jak: heretycy, Żydzi, trędowaci. Zastosowanie tego rodzaju procedury intelektualnej i instytucjonalnej miało służyć lepszej konsolidacji społeczeństwa i obronie jego wartości w okresie pełnego średniowiecza. Inspiracją dla ujęcia krytycznego była też nowatorska praca francuskiego historyka Emmanuela Le Roy Ladurie pt. Montaillou, village occitan de 1294 à $1324(1975)^{55}$. Autor wykazał w niej dużą wartość dokumentów inkwizycyjnych (protokoły inkwizytora Jakuba Fourniera z lat 1318-25) dla całościowych badań antropologicznych małej społeczności w średniowieczu (tytułowa wioska Montaillou na pogórzu Pirenejów).

\section{Historycy francuscy}

Do twórców historiografii krytycznej dysydencji katarskiej należy zaliczyć badaczy francuskich starszego pokolenia: Monique Zerner, Jeana-Louisa Bigeta i Jacquesa Chiffoleau oraz ich uczniów: Uwe Brunna, Juliena Théry'ego i Laurenta Albareta ${ }^{56}$.

Za pracę założycielską dla rozwoju studiów dekonstrukcjonistycznych nad kataryzmem trzeba uznać tom studiów Inventer l'hérésie? pod redakcją Monique Zerner, który ukazał się w 1998 r. i jest wynikiem spotkań zorganizowanych w Nicei w latach 1993-9657. Składa się on z dziesięciu artykułów

52 Por. T. Manteuffel, Naissance d'une hérésie, [w:] Hérésies et sociétés, s. 97-103; rozwinięcie tezy w: Narodziny herezji, Warszawa 1963, PWN. Na temat badań herezjologicznych T. Manteuffla zob.: S. Bylina, Polskie badania nad ruchami heretyckimi w średniowieczu, „Przegląd Historyczny”, 86, 1995, s. 307-308.

53 Por. T. Manteuffel, Hérésies et sociétés, s. 399.

54 Por. R. I. Moore, The Formation of a Persecuting Society. Power and Deviance in Western Europe 950-1250, Oxford 1987, Blackwell.

55 Por. E. Le Roy Ladurie, Montaillou, village occitan de 1294 à 1324, Paris 1975, Gallimard (wyd. polskie: Montaillou, wioska heretyków 1294-1324, tł. E. D. Żółkiewska, Warszawa 1988, PIW).

56 Por. J.-Ph. Marcoux-Fortier, „Ritus hereticorum”, s. 22-25.

57 Por. Inventer l'hérésie? Discours polémiques et pouvoirs avant l'Inquisition, dir. M. Zerner, Nice 1998, Centre d'études médiévales. 
(dwóch odnoszących się do antyheretyckiego dyskursu Kościoła w późnej starożytności ${ }^{58}$ i ośmiu pozostałych związanych z tworzeniem się takiego dyskursu w średniowieczu, w okresie przed powstaniem inkwizycji ${ }^{59}$ ). W omawianej książce ważny jest też wstęp autorstwa Monique Zerner ${ }^{60}$. Umieszcza ona studia badaczy związanych z ośrodkiem nicejskim w nurcie badań nad pismem i władzą pisma. Nawiązuje tu do anglosaskiej literacy, co po polsku można przetłumaczyć po prostu jako „piśmienność”, ale ostatnio słowo to oddaje się też za pomocą terminu „alfabetyzm”, oznaczającego ogół kompetencji pozwalających jednostce uczestniczyć w społeczeństwie (opartym na piśmie). Zerner zastrzega się jednak, że historiografia anglosaska analizuje związki pomiędzy tym, co pisane, a tym, co mówione, natomiast badacze francuscy skupiają się przede wszystkim na tekstach pisanych i na tym, jak posługują się nimi instytucje kościelne wobec niepiśmiennych najczęściej przedstawicieli dysydencji religijnych. Tak więc przedmiotem badań byłby tu przede wszystkim antyheretycki dyskurs kościelny, który bardziej ustanawiał, niż opisywał przedmiot swojego zainteresowania, a więc wykazywał tendencję do „wymyślania herezji”. Monique Zerner jest też redaktorką pracy zbiorowej L’histoire du catharisme en discussion (2001). Autorzy zamieszczonych w niej artykułów podważają wiarygodność Dokumentu Niketasa (Charte de Niquinta), źródła potwierdzającego bogomilską inspirację dysydencji katarskiej, ponadto próbę (częściowo udana) zaszczepienia na Zachodzie dualizmu radykalnego oraz istnienie międzynarodowej konfederacji katarskich biskupstw ${ }^{61}$.

Wzorcowym przykładem realizacji założeń dotyczących badania dyskursu kościelnego skierowanego przeciw kontestatorom religijnym jest praca francuskiego historyka, ucznia Monique Zerner, Uwe Brunna pt. Des contestataires aux ,cathares” $(2006)^{62}$. Analizuje on dyskurs antyheretycki w Nadrenii od 1100 do 1233 r. w związku z dysydencją określaną jako „katarska”, która pojawiła się tam w połowie wieku XII. Próby zdefiniowania i odparcia wspomnianej kontestacji religijnej podjęli się przede wszystkim

\footnotetext{
58 Por. ibidem, s. 15-55.

59 Por. ibidem, s. 57-262.

60 Por. ibidem, s. 7-13.

61 Por. L'histoire du catharisme en discussion. Le „concile” de Saint-Félix (1167), dir.

M. Zerner, Nice 2001, Centre d'études médiévales.

62 Por. U. Brunn, Des contestataires aux „cathares”. Discours de réforme et propaganda antihérétique dans les pays du Rhin et de la Meuse avant l'inquisition, Paris 2006, Institute d'études augustiniennes.
} 
prepozyt premonstrateński Everwin ze Steinfeld oraz opat benedyktyński Eckbert z Schönau. To ten ostatni był głównym inicjatorem walki przeciw dysydentom, z którymi miał dwukrotnie kontakt: w Bonn (przed 1155) oraz w Kolonii (1163). W swoim traktacie Liber contra hereses katarorum (1163-64) zwalcza dziesięć tez dysydentów i, jak twierdzi Uwe Brunn, łączy informacje zebrane od dysydentów oraz wiadomości zaczerpnięte z pism św. Augustyna i z tekstów prawa kanonicznego w taki sposób, że niewiele mówi w istocie o rzeczywistości „katarskich” kontestatorów. A zatem uczony benedyktyn, konstruując dyskurs katarski, przypisał dysydentom nadreńskim nazwę katari, pod którą zebrał cechy heretyków, nazywanych przez Ojców Kościoła cathari, catharistae i cataphrigii ${ }^{63}$. Ważną cechą tej konstrukcji intelektualnej był dualizm wyrażający się w odrzucaniu małżeństwa i pokarmów zwierzęcych. Liber Eckberta wyznacza zatem, według historyka, początek „kataryzmu” jako konstrukcji dyskursu kościelnego. Uwe Brunn podejmuje też próbę rekonstrukcji rozwoju kościelnego dyskursu na temat katarów, a w związku z tym usiłuje wyjaśnić, jak to się stało, że nazwa ta w drugiej połowie XIII w. była stosowana także do kontestatorów włoskich i langwedockich. Francuski badacz twierdzi, że do Italii określenie „katar” mogło zostać przyniesione za sprawą arcybiskupów Kolonii, którzy byli jednocześnie wysokimi urzędnikami Królestwa Włoch (jednemu z nich Eckbert dedykował swoje dzieło). Określenie to we Włoszech zostało po raz pierwszy połączone z wyraźną doktryną katarską i dualizmem typu umiarkowanego w Manifestatio haeresis catharorum przypisywanej Bonacursusowi i datowanej na ostatnią ćwierć XII stulecia. Z kolei terminu „katar” w odniesieniu do południowofrancuskich dysydentów (albigensów) użyto bardzo późno, bo dopiero w roku 1250. Zrobił to włoski inkwizytor Rainerius Sacconi w Summa de Catharis et de pauperibus leonistis; Brunn dodaje, że nazwa ta pojawia się w odniesieniu do langwedockich kontestatorów tylko w jednym typie źródeł, mianowicie w podręcznikach dla inkwizytorów, nie znajdujemy jej natomiast w aktach inkwizycji.

Francuskim badaczem starszego pokolenia, którego można zaliczyć do grupy dekonstrukcjonistów, jest Jean-Louis Biget. Opublikował on artykuł we wspomnianym już tomie Inventer l'hérésie ${ }^{\text {T4 }}$, a za reprezentatywny dla jego długiej kariery badawczej należy uznać zbiór tekstów Hérésie et inquisition

63 Zob. też: U. Brunn, "Cathari”, "catharistae” et "cataphrygae”, ancêtres des cathares du XIIe siècle?, „Heresis”, 36-37, 2002, s. 183-200.

64 Por. J.-L. Biget, Les Albigeois. Remarques sur une dénomination, [w:] Inventer l'hérésie?, s. 219-256. 
dans le Midi de la France $(2007)^{65}$. W książce tej zajmuje się on ważnymi zagadnieniami historii religijnej południa Francji od XII do początku XIV w.: narodzinami dysydencji religijnej, której źródłem był antyklerykalizm, a nie wpływ bogomiłów, herezją jako konstrukcją ideologii Kościoła oraz początkiem i działaniem inkwizycji na wspomnianym obszarze. Autor zauważa, że dysydencję należy rozpatrywać w szerokiej perspektywie sytuacji Kościoła oraz realiów kulturalnych, społecznych i politycznych epoki. W związku z powyższym Biget wysuwa postulat, żeby źródła polemiczne czytać ze świadomością całego wieloaspektowego kontekstu historycznego.

Przedstawicielem młodszej generacji francuskich historyków szkoły krytycznej jest Julien Théry. W ważnym artykule z 2002 r. pt. L'hérésie des bons hommes. Comment nommer la dissidence religieuse non vaudoise ni béguine en Languedoc ${ }^{36}$ rozważa on problem, jak nazywać langwedockich dysydentów, tradycyjnie określanych jako „katarzy” lub „albigensi”, skoro nazwy te są konstrukcjami dyskursu kościelnego. Z tego samego powodu podważa też realność dwóch ważnych cech tej kontestacji religijnej, podkreślanych przez historiografię tradycyjną, mianowicie - teologii dualistycznej i międzynarodowej organizacji katarów. Aby wyjaśnić to zagadnienie, Théry odwołuje się do źródeł inkwizycyjnych, które - jak twierdzi - spośród świadectw antyheretyckich najmniej zniekształcają rzeczywistość dysydentów. W konkluzji proponuje używać określenia „herezja dobrych ludzi” na kontestację w Langwedocji, która nie jest ani waldeńska, ani begińska. Dodaje przy tym, że było to zjawisko bez ściśle określonej tożsamości, co najwyżej można mu przypisać ewangeliczne podstawy.

2. Badacze z innych krajów

Do grona historyków ujęcia krytycznego należy także Amerykanin Mark Gregory Pegg. Jest on autorem dwóch znaczących pozycji: The corruption of Angels ${ }^{67}$ wydanej w 2001 r. oraz opublikowanej siedem lat później A Most Holy $\mathrm{War}^{68}$. Pierwsza z nich to próba zrozumienia życia społecznego

\footnotetext{
65 Por. J.-L. Biget, Hérésie et inquisition.

66 Por. J. Théry, L’hérésie des bons hommes. Comment nommer la dissidence religieuse non vaudoise ni béguine en Languedoc (XIIe-début du XIVe siècle)?, „Heresis”, 36-37, 2002, s. 75-117.

${ }^{67}$ Por. M. G. Pegg, The Corruption of Angels. The Great Inquisition of 1245-1246, Princeton 2001, Princeton UP.

68 Por. M. G. Pegg, A Most Holy War. The Albigensian Crusade and the Battle for Christendom, Oxford 2008, Oxford UP (wyd. polskie: Najświętsza wojna).
} 
w Langwedocji w pierwszej połowie XIII w. na podstawie rękopisu inkwizycyjnego 609 z Biblioteki Miejskiej w Tuluzie, stanowiącego zapis wielkiego śledztwa z lat 1245-46. A Most Holy War z kolei została poświęcona krucjacie przeciw albigensom, opisanej tu jako zmagania między dwiema wizjami chrześcijaństwa: jedną, odwołującą się do religii instytucjonalnej, która wykorzystuje ideologię, propagandę i przemoc, oraz drugą, odnoszącą się do religii tolerancyjnej. Ta pierwsza wiązała się z Kościołem rzymskim, druga zaś z „wysoko rozwiniętą kulturą chrześcijaństwa”, która spontanicznie zrodziła się w Langwedocji.

Także czeski badacz David Zbíral wpisuje się w ramy historiografii dekonstrukcjonistycznej. W swojej dobrze udokumentowanej książce Největši hereze $(2007)^{69}$ uznaje proces konstruowania scentralizowanej herezji dualistycznej za instrument tworzenia społeczeństwa chrześcijańskiego w średniowiecznej Europie, potrzebującego silnej kontroli przestrzegania norm wiary i reguł słusznego postępowania. Autor twierdzi, że zwalczający dysydencję zmierzali do jej wykluczenia i zniszczenia, ale przede wszystkim - do jej dokładnego zdefiniowania. Dlatego więc kataryzm jako konstrukcja intelektualna uzyskał cechy zorganizowanego przeciw-kościoła z wyraźną dualistyczną doktryną - antyświatową i dającą się łatwo wpisać w odwieczny łańcuch herezji.

W kontekście podejścia krytycznego trzeba wspomnieć jeszcze włoską badaczkę Caterinę Bruschi, choć nie wszystkie jej poglądy mieszczą się w zakresie omawianego tu stanowiska. Jest ona edytorką traktatu świeckiego autora, zwalczającego włoskich heretyków (głównie katarów), pt. Liber Suprastella ${ }^{70}$ oraz współedytorką dwóch tomów (25 i 26) nowożytnych kopii dokumentów inkwizycyjnych pochodzących ze zbioru Jeana de Doata (Collection Doat) w Bibliothèque nationale de France ${ }^{71}$. Napisała także wydaną w 2009 r. pracę The Wandering Heretics of Languedoc ${ }^{72}$, opartą na analizie tomów 21-26 ze wspomnianej Collection Doat. W książce

69 Por. D. Zbíral, Největši hereze. Dualismus, učenecká vyprávèní o katarství a budování křestanské Evropy, Praha 2007, Argo.

70 Por. S. Burci, Liber Suprastella, a cura di C. Bruschi, Roma 2002, Istituto Storico Italiano per il Medio Evo.

71 Por. Inquisitors and Heretics in Thirteenth-Century Languedoc. Edition and Translation of Toulouse Inquisition Depositions, 1273-1282, ed. P. Biller, C. Bruschi, S. Sneddon, Leiden 2011, Brill.

72 Por. C. Bruschi, The Wandering Heretics of Languedoc, Cambridge 2009, Cambridge UP. 
tej Bruschi zajmuje się mobilnością katarów i innych grup dysydenckich $\mathrm{w}$ Langwedocji, a ponadto jeden $\mathrm{z}$ rozdziałów poświęca metodologii krytyki szczególnego rodzaju źródła, jakim są protokoły inkwizycyjne ${ }^{73}$. Autorka stoi na stanowisku, wbrew niektórym sceptycznym badaczom, że po zastosowaniu złożonej procedury krytycznej można jednak „usłyszeć” niezniekształcone wypowiedzi przesłuchiwanych (wymienia tu cztery „filtry”, które blokują dostęp do poszukiwanych informacji i wiążą się z: procedurą śledztwa, procesem protokołowania, dynamiką narracji oraz kopiowaniem zapisanych tekstów). To głębokie i kontekstowe badanie świadectw inkwizycyjnych dobrze odpowiada zasadom ujęcia krytycznego. Poza nimi jest już jednak przekonanie badaczki, że kataryzm był realnym zjawiskiem historycznym, którego istotę stanowiła idea „żywego, podróżującego Kościoła”, cechującego się wyraźną strukturą ${ }^{74}$.

\section{Podsumowanie}

Przedstawiciele historiografii krytycznej (dekonstrukcjonistycznej) podważają rzeczywistość społeczną kataryzmu, odnajdując jego główne cechy, takie jak nazwa „katarzy”, dualistyczna doktryna oraz spójna i zhierarchizowana organizacja kościelna w sferze zjawisk wyobrażonych. Mówiąc innymi słowy, dekonstrukcjoniści uznali, że obraz kataryzmu prezentowany przez historiografię tradycyjną jest w dużej mierze przejęciem konstrukcji herezji dualistycznej stworzonej przez średniowiecznych autorów kościelnych.

Wysunięcie takiej hipotezy było możliwe głównie dzięki uwzględnieniu dwóch innych koncepcji: teorii średniowiecznego społeczeństwa wykluczającego i prześladującego, które posługuje się instytucjami religijnymi i świeckimi, aby zwalczać różnego typu kontestacje (R. I. Moore) oraz założenia, że zdecydowana większość świadectw na temat kataryzmu została wytworzona przez stronę kościelną lub autorów z kościołem związanych, a co za tym idzie, należy analizować je szczególnie starannie ze względu na niebezpieczeństwo zniekształceń. Dogłębne i kontekstowe badanie źródeł kościelnych doprowadziło do odkrycia określonych właściwości dyskursu kościelnego, którego autorzy - według historyków reprezentujących omawiane podejście - „wymyślili” herezję dualistyczną. Badacze ci uznali, że świadectwami, które mogą najwięcej powiedzieć

73 Por. ibidem, s. 11-49.

74 Por. ibidem, s. 194. 
o rzeczywistości dysydentów - po zastosowaniu odpowiedniej procedury krytycznej - są protokoły trybunałów inkwizycyjnych.

Chociaż analiza antyheretyckiego dyskursu kościelnego i krytyka źródeł inkwizycyjnych jest najważniejszym wkładem historiografii dekonstrukcjonistycznej, to badacze tego ujęcia podjęli także trud ustalenia nazwy i treści dysydencji nazywanej przez historyków „tradycyjnych” - katarską. Dla Langwedocji zaproponowano nazwę „herezja dobrych ludzi” od boni homines i bone femine, określeń pojawiających się w zeznaniach przed trybunałami inkwizytorów. Jeśli natomiast chodzi o treść tej kontestacji religijnej, dekonstrukcjoniści akcentują nieokreśloność doktryny i brak instytucjonalizacji, a jedyne pewne cechy, na które wskazują, to antyklerykalizm i inspiracja Ewangelią. Sporna pozostaje kwestia dualizmu: Julien Théry utrzymuje, że dualizm, a właściwie antydualizm, stanowił stałą cechę myślenia autorów kościelnych średniowiecza ${ }^{75}$, podczas gdy Jean-Louis Biget twierdzi, iż był on wynikiem ewolucji postawy ewangelicznej samych dysydentów ${ }^{76}$.

\section{Wnios ki}

Na podstawie przeglądu głównych stanowisk w najnowszych badaniach nad dysydencją nazywaną tradycyjnie katarską wyłania się obraz tego zjawiska wyznaczony przez trzy istotne czynniki. Pierwszym są wpływy religijne ze Wschodu (tylko bogomilskie czy może aż gnostyckie lub nawet zaratusztriańskie), drugim - wynikająca z przemian społecznych potrzeba odnowienia zachodniego Kościoła i związane z nią dążenie do nowych, inspirowanych Ewangelią, form religijności, trzecim zaś dyskurs kościelny, który miał silny wpływ na ukształtowanie wizerunku wspomnianej dysydencji religijnej (lub dysydencji religijnych przedstawianych jako jedna dualistyczna herezja) wśród średniowiecznych wiernych i u dzisiejszych badaczy. Można w związku z tym przyjąć, że współczesne historiograficzne ujęcia dysydencji katarskiej uwzględniają metodologię trzech dyscyplin:

- historii religii (nurt egzogeniczny ujęcia tradycyjnego) - kataryzm jako rezultat zaszczepienia dualizmu ze Wschodu;

- historii społecznej i opartej na niej historii religijności (nurt endogeniczny ujęcia tradycyjnego) - kataryzm jako formacja religijna powstała w środowisku zachodniego chrześcijaństwa;

75 Por. J. Théry, op. cit., s. 77.

76 Por. J.-L. Biget, Hérésie et inquisition, s. 119. 
- historii dyskursu (ujęcie krytyczne) - kataryzm jako konstrukcja dyskursu kościelnego.

Dopiero rzeczowa debata ${ }^{77}$, ustalenie proporcji albo hierarchii ważności między głównymi nurtami współczesnych badań nad dysydencją katarską, pozwoli zbliżyć się do prawdy o wspomnianym fenomenie historyczno-religijnym i orzec, w jakim stopniu był on realnym zjawiskiem społecznym (a jeśli tak, to jakiego pochodzenia), a w jakim stopniu efektem wyobrażeń. Ale już dziś możemy powiedzieć, że kontestacja religijna nazywana tradycyjnie katarską była bardziej złożona - ale i badawczo znacznie bardziej interesująca - niż wydawało się to historykom jeszcze dwadzieścia czy trzydzieści lat temu.

\section{Aneks}

\section{Wybrana bibliografia prac o historii historiografii kataryzmu}

R. Manselli, L'eresia del male, Napoli 1963, Morano, s. 106-145.

D. Walther, A Survey of Recent Research on the Albigensian Cathari, „Church History", 34, 1965, s. 146-177.

E. Delaruelle, L'état actuel des études sur le catharisme, „Cahiers de Fanjeaux”, 3: Cathares en Languedoc, 1968, s. 19-41.

E. Werner, Geschichte des mittelalterlichen Dualismus. Neue Fakten und alte Konzeptionen, „Zeitschrift für Geschichtswissenschaft”, 23, 1975, s. 538-551. „Cahiers de Fanjeaux”, 14, 1979: Historiographie du catharisme (podstawowa pozycja do historii historiografii kataryzmu; zawiera artykuły na temat badań

77 Przykładem takiej dyskusji może być polemika wokół tyleż ważnego, co spornego Dokumentu Niketasa (Charte de Niquinta), o którym wspomniałem już przy omówieniu dorobku Monique Zerner. Spór został zapoczątkowany w 2001 r. pracą zbiorową pod redakcją wspomnianej historyczki i zwolenniczki ujęcia krytycznego, co z kolei spotkało się z protestem Michela Roqueberta oraz Francesco Zambona (Où en est le problème des Actes du concile de St-Félix? À propos de „L'histoire du catharisme en discussion”, [w:] Les Cathares devant l'histoire, s. 135-144). Zerner, broniąc swojego stanowiska, odpowiedziała artykułem Mise au point sur "Les cathares devant l'histoire" et retour sur "L'histoire du catharisme en discussion”. Le débat sur la charte de Niquinta n'est pas clos („Journal des savants", 2, 2006, s. 253-273). Ostatnim, jak do tej pory, głosem w dyskusji jest publikacja Davida Zbírala umieszczona w wydaniu krytycznym Dokumentu Niketasa z 2010 r. (Édition critique de la charte de Niquinta, [w:] 1209-2009, cathares. Une histoire à pacifier? Actes du colloque international tenu à Mazamet les 15, 16 et 17 mai 2009, dir. A. Brenon, Portet-sur-Garonne 2010, Loubatières, s. 45-52). 
nad kataryzmem w epoce nowożytnej, w XIX i w XX w., a także na temat kataryzmu w kontekstach pozahistoriograficznych).

L. Albaret, Le point sur l'historiographie du catharisme aujourd'hui, „Cahiers d'Histoire. Revue d'histoire critique", 70, 1998, s. 7-18.

Cathares et camisards. L'oeuvre de Napoléon Peyrat (1809-1881), dir. P. Cabanel, Ph. de Robert, Montpellier 1998, Presses du Languedoc.

Catharisme: édifice imaginaire. Actes du 7e colloque du Centre d'Etude Cathares/ René Nelli, Carcassonne, 29 août-2 septembre 1994, dir. J. Berlioz, J.-C. Hélas, Carcassonne 1998, Centre d'étude cathares. Stąd: J. Blanc, Vision critique des clercs face au catharisme, s. 39-45 (artykuł omawia przede wszystkim publikacje nowożytne); Y. Hagman, Les historiens des religions et les constructions des ésotéristes, s. 131-143 (kataryzm w perspektywie tradycji ezoterycznej od zaratusztrianizmu po New Age oraz w ujęciu „die Religions-Geschichtliche Schule"); M. Jas, L'ortodoxie protestant, le rêve albigeoise, Schmidt et Peyrat, s. 97-117; P. Jimenez, La vision médiévale du catharisme chez les historiens des annees 1950: un néo-manicheisme, s. 65-96; D. Müller, La perspective de l'historiographie allemande, s. 47-63.

B. Hamilton, The State of Research. The Legacy of Charles Schmidt to the study of Christian dualism, „Journal of Medieval History”, 24, 1998, s. 191-214.

M. G. Pegg, Historiographical essay on Cathars, Albigenses and good men of Languedoc, „Journal of Medieval History”, 27, 2001, s. 181-195.

F. Sabaté, Un précurseur des études sur le catharisme en Catalogne: Jordi Ventura Subirats (1932-1999), „Heresis”, 34, 2001, s. 131-145.

$\mathrm{Ph}$. Martel, Les cathares et l'Histoire. Le drame cathare devant ses historiens (18201992), Toulouse 2002, Privat.

L. Albaret, John Hine Mundy (1917-2004). Un Américain à Toulouse, „Heresis”, 2004, 41, s. 9-12 (tu także bibliografia prac J. H. Mundy'ego na temat kataryzmu i południowej Francji w średniowieczu).

R. Soula, Les cathares entre légende et histoire. La mémoire de l'albigéisme du XIXe siècle à nos jours, Puylaurens 2004, Institut d'Estudis Occitans (praca jest poświęcona instrumentalizacji pamięci historycznej kataryzmu w XIX i XX w.).

M. Roquebert, Le "déconstructionisme” et les études cathares, [w:] Les cathares devant l'histoire. Mélanges offerts à Jean Duvernoy, dir. M. Aurell, Cahors 2005, L'Hydre, s. 105-133.

J.-L. Biget, Hérésie et inquisition dans le midi de la France, Paris 2007, Picard, s. 64-73 (ukazuje historiografię dotyczącą pochodzenia kataryzmu). 
P. Jiménez-Sanchez, Les catharismes. Modèles dissidents du christianisme médiéval (XIIe-XIIIe siècles), Rennes 2008, Presses Universitaires de Rennes, s. 21-48.

„Studia Religiologica”, 41, 2008: $Z$ religijnych zagadnień średniowiecza (zawiera recenzje książek polskich autorów na temat dysydencji dualistycznej w średniowieczu: J. Borkowskiej, Kataryzm. Spór o dualizm średniowieczny, s. 217-220; P. Czarneckiego, Średniowieczny lucyferianizm (XIII-XV wiek), s. 221-223; M. Dobkowskiego, Kataryzm. Historia i system religijny, s. 229235; a także artykuł M. Höffner, Kataryzm - między mitem a historią, s. 201215 - o kataryzmie w kontekstach pozahistoriograficznych).

S. Grau Torras, Historiografia del catarismo en Cataluña. Estudios y documentos (siglo XIII), „Acta historica et archaeologica mediaevalia”, 30, 2010, s. 375-408.

P. Jiménez-Sanchez, Retour sur la construction historiographique des origines orientales du catharisme, [w:] 1209-2009, cathares. Une histoire à pacifier? Actes du colloque international tenu à Mazamet les 15, 16 et 17 mai 2009, dir. A. Brenon; Portet-sur-Garonne 2010, Loubatières, s. 11-23.

J.-Ph. Marcoux-Fortier, „Ritus hereticorum”. Les rites de l'hérésie des „bons hommes” comme construction cléricale au sein de deux registres d'Inquisition (Albi, 1286-1287 et 1299-1300), Québec 2011, Université Laval, s. 5-27 (wersja elektroniczna: http://theses.ulaval.ca/archimede/fichiers/27725/27725.pdf; dostęp: 04.04.2014).

J. O. Ward, Introduction. Australian Cathar Studies, „Journal of Religious History”, 35, 2011, s. 469-477 (wstęp do specjalnego numeru „Journal of Religious History", 35/4, 2011, poświęconego katarom; skrótowo przedstawia najważniejsze nurty we współczesnych badaniach nad kataryzmem langwedockim). 